RESUMO

Trata-se de uma discussão de dois casos clínicos, relativos ao atendimento de adolescentes do sexo masculino, os quais, a despeito das diferenças de seus modos de vida, costumes e tradições, apresentam algo em comum: uma forma sinuosa de encontro com o masculino, $e$ que, diante da falta de um olhar paterno voltado realmente para eles, encontram na música a ancoragem narcisica que lhes faltou. E, na análise, a possibilidade de elaboração a-posteriori de um caminho de algum modo já percorrido pela via musical.

Descritores: acesso ao masculino; homossexualidade psíquica; sublimação estética; adolescentes; música

\section{A MÚSICA E A PSICANÁLISE ENTRE OS ADOLESCENTES}

\author{
Mônica G. T. do Amaral
}

\ntrodução

Como psicanalista e docente que contribui para a formação de professores do ensino médio e fundamental, preocupo-me particularmente com as possibilidades de subjetivação/dessubjetivação do adolescente no mundo de hoje; mundo em que participam a expressão alternada do desejo pelo outro e o retorno sobre sua própria intimidade, um movimento que não se faz sem percalços, uma vez que se vê interrompido, quando não limitado, pela fragmentação e descontinuidade das relações. Em uma época em que prevalece a solidão e, em contrapartida, a complacência ao exibicionismo e ao voyeurismo, parece-me fundamental recuperar a noção de pudor; recuperá-la tanto para as meninas, como para os meninos, como forma de resguardar, no campo teórico-clínico, a intimidade do sujeito psíquico em formação, que na adolescência fica mais exposta diante da explosão da sexualidade.

Movida por tais preocupações, tenho me dedicado a repensar a clínica psicanalítica dos funcionamentos-limite na adolescência. Nesse sentido, comecei uma pesquisa há cerca de 5 anos, envolvendo

Docente da Faculdade de Educação da USP e Membro Associado da Sociedade Brasileira de Psicanálise - SBPSP. 
o atendimento terapêutico de jovens com sérios problemas na construção de sua subjetividade; inicialmente, junto ao Departamento de Psiquiatria da Infância e da Adolescência da Escola Paulista de Medicina e, mais recentemente, há dois anos, no CAPS da Lapa ${ }^{1}$, como parte de minha pesquisa desenvolvida na Faculdade de Educação da Universidade de São Paulo (USP).

Apresentarei dois casos clínicos relativos ao atendimento de adolescentes do sexo masculino: um deles junto ao serviço público de atendimento à saúde mental do adolescente no CAPS da Lapa, em equipe multidisciplinar; o outro, em atendimento individual. Os dois casos, a despeito das diferenças de seus modos de vida - um oriundo de uma família de roqueiros, que nos anos 60 cultivara o modo de vida hippie e o outro, de uma família estruturada segundo os moldes das sociedades antigas, bastante religiosa, e amante da música erudita -, apresentam algo em comum: uma forma bastante sinuosa de se defrontar com o masculino. $\mathrm{Na}$ falta de um olhar paterno voltado realmente para eles, encontram na música a ancoragem narcísica que lhes faltara, e, na análise, a possibilidade de elaboração a-posteriori de um caminho de algum modo já percorrido... pela via musical.

Nesta exposição, apresento inicialmente uma breve reflexão sobre o que se tem pesquisado sobre o funcionamento limite ${ }^{2}$ ou borderline na adolescência, para expor, em seguida, a evolução e os impasses encontrados nos atendimentos terapêuticos dos dois adolescentes mencionados acima. Proponho-me ainda a pensar sobre o impacto do "apagar do pai" na dinâmica emocional de alguns adolescentes que apresentam um funcionamento-limite e que estão em estado permanente de sofrimento psíquico. Alguns, pedindo ajuda; outros, negando-se a qualquer intercâmbio com o mundo adulto, o que dificulta, muitas vezes, o próprio processo terapêutico. Trabalho aqui com a idéia de que a homossexualidade psíquica, interrompida com o apagar do pai, é retomada por alguns adolescentes com a música, por meio da qual dão início a um trabalho sublimatório fundamental para o recriar-se e ir ao encontro do masculino.

\section{O apagar do pai, as patologias do agir e o funcionamento-limite}

Em artigo publicado sob o título "A adolescência na contemporaneidade - reflexões sobre a vida danificada" (Amaral, 2003), eu sustentava que um problema central da atualidade é que 
se haviam levantado obstáculos efetivos à subjetivação. Desses obstáculos, as conseqüências danosas faziam-se sentir não apenas entre aqueles que se encontravam à margem do sistema, mas, sobretudo, entre os jovens - independentemente da classe social a que pertenciam; jovens cujos contornos apareciam cada vez mais tênues, por falta absoluta de um lugar social em que pudessem sentir-se partícipes de um projeto, o que não se restringia de modo algum ao âmbito familiar, o qual se encontrava, ele também, na dependência de um projeto global de modernidade.

Se acompanharmos as idéias sustentadas por Lipovetsky (1993), em L'Ere du vide, identificamos a passagem do individualismo limitado ao individualismo ilimitado, dando lugar ao narcisismo pós-moderno, pautado por uma sociedade que desliza sem vínculos sólidos, nem possui tampouco bases emocionais estáveis. E, o pior, dando lugar a relações em que prevalece a "fragilização dos limites" - entre o domínio privado e o público, entre as gerações, o dentro e o fora, enfim, entre o eu e o outro.

Ao mesmo tempo, como salienta Jeammet e Corcos (2001/ 2005), esse enfraquecimento dos limites, particularmente no interior da dinâmica familiar, dá-se concomitantemente ao enfraquecimento das interdições e em benefício do aumento das exigências narcísicas. $\mathrm{O}$ amor responsável entre pais e filhos dá lugar à exigência de competência e de resultados e, se olharmos com uma lupa para a natureza do vínculo estabelecido entre eles, veremos que prevalece muito mais uma relação de controle sobre a mente e o corpo da jovem geração, demonstrando-se, assim, a incapacidade atual das gerações mais velhas de fazer o luto da separação de seus filhos, tão necessária para a construção de sua autonomia.

Jeammet (1994), em seu artigo Approche psychodynamique de la psychopatology de l'agir à l'adolescence, observa que o que ele chama de "patologia do agir" na adolescência ilustra de maneira exemplar a articulação entre o mundo externo e interno. Jeammet está se referindo a um conjunto de atuações-limite (entre o corpo e a mente, entre o externo e o interno), a que o adolescente recorre em razão de sua fragilização narcísica. Salienta, entretanto, que uns fazem de sua fragilidade um motor criativo para suas vidas, enquanto outros afundam em um "destino marcado pela repetição, o masoquismo e a auto-destruição" ( Jeammet, 1994, p. 75). E para tanto vai depender do grau de ressonância propiciado pelo mundo adulto às necessidades psíquicas dos jovens, favorecendo ou impedindo o jogo de investimentos e contra-investimentos.

Em outro artigo, Libertés internes et libertés externes, importance et spécificité de leur articulation à l'adolescence (Jeammet, 1989), o autor sustenta que o paradoxo inelutável do adolescente na atualidade. Esse 
paradoxo - de ver-se pressionado pela necessidade do objeto para concluir seu processo de identificação (necessário à sua autonomia) e, ao mesmo tempo, pelo receio de ver ameaçada essa mesma autonomia tende a exacerbar-se, conduzindo-o muitas vezes à atuação, em grande medida devido à transformação profunda do quadro social em que se faz presente o aumento de exigências de performance, mais do que de competência - ao mesmo tempo em que se liberalizam os costumes. Em razão dessas exigências exacerbadas de responsabilidade e competência, ficam muito mais inseguros quanto a suas capacidades.

Se acompanharmos o raciocínio de Jeammet, veremos que a adolescência põe em questão o conjunto dos pontos de apoio que asseguram a autonomia do sujeito: ou seja, suas bases narcísicas, assim como o caráter diferenciado das estruturas internas e Imagos parentais, e que tudo isso reforçaria o antagonismo entre o narcisismo (o amor de si) e a relação objetal (de amor ao outro). Diante de exigências tão contraditórias que se impõem na atualidade ao jovem, tal antagonismo tende a se exacerbar.

Jeammet menciona duas formas possíveis, dentre as inúmeras existentes, que o jovem encontra para fazer face ao incremento da oposição entre o amor do eu e o amor pelo outro ("Ou eu ou o outro!"). Existem as condutas negativistas, opondo-se a todo e qualquer intercâmbio com o mundo adulto, a ponto de desencadear um verdadeiro movimento antiintrojetivo, que atinge não somente as identificações (que, por sua vez, aguardam uma espécie de acabamento a ser feito na adolescência), como pode chegar a um verdadeiro apagamento dos traços dos vínculos mantidos com as figuras parentais.

A homossexualidade psíquica seria uma saída, no sentido de permitir a retomada dos "movimentos introjetivos estruturantes" (Jeammet, 1994). Trata-se do que usualmente concebe-se como uma resolução negativa do Édipo. Uma resolução que pode propiciar um verdadeiro conforto em suas bases narcísicas e que é obtido graças a uma identificação bem sucedida com a figura parental do mesmo sexo. O que pode acontecer tranqüilamente na primeira infância e complicar-se na adolescência, diante da recusa do jovem (ou da jovem) a ser literalmente absorvido(a) narcisicamente pelo progenitor que não admite que seu filho seja diferente de si mesmo. Contudo, esse processo pode se complicar desde cedo, no caso de a introjeção tornarse insuportável pelo grau de excitação que ela comporta. Os fracassos na introjeção são traduzidos seja por relações de antipatia, a começar pelo assédio - em todo caso sempre com tonalidade sadomasoquista - da figura parental do mesmo sexo, e depois com seus substitutos ou representantes, que lhes deveriam dar suporte social e ideológico (estou me referindo aqui, sobretudo, aos educadores).

Passemos à apresentação dos casos clínicos. 


\section{$D$, o garoto que gostava do rock dos anos 60}

D. é um garoto de 17 anos que veio, a pedido da mãe, para um atendimento psiquiátrico, por se encontrar desligado da escola havia 3 anos. Desde então, foi se afastando dos amigos, da rua e de qualquer contato social. Vivia em casa, ou melhor, trancado em seu quarto, escutando música ou brincando no computador.

D. vinha de uma família que parecia ter tido um histórico de vida do tipo "hippie", daí ele se interessar por bons músicos de rock, blues, etc. Um gosto que foi cultivando a partir da influência de sua avó, assim como do pai e da mãe. E foi esse gosto musical que ele pode usufruir com prazer com o psiquiatra, Dr. O., membro da equipe de atendimento do CAPS. Como D. se recusasse a freqüentar o que quer que fosse, sugeri ao Dr. O. que fizéssemos um atendimento simultâneo - eu acompanharia mais os aspectos fantasmáticos e Dr. O. as questões do dia-adia; o que, aliás, ele fez com maestria. Aproveitando-se do fato de ser um profundo conhecedor das músicas de rock dos anos 60 , passaram a ouvir os Cds trazidos por D. durante os encontros terapêuticos. Contei à equipe que a análise de D. estava caminhando bem, mas como senti que não poderia contar com os pais, como figuras parentais capazes de oferecer a ele um apoio seguro para o seu crescimento e de acompanhá-lo nessa saída de casa e retorno ao mundo, ponderei com Dr. O. que atendê-lo conjuntamente (embora em separa- 
do, cada um uma vez por semana), talvez fosse uma experiência interessante. A idéia era reconstruir com $\mathrm{D}$. as figuras parentais que pareciam muito frágeis, externa e internamente e, ao mesmo tempo, oferecer-lhe a possibilidade de dividir entre dois profissionais a transferência maciça que ele demonstrou dificuldade de suportar em uma relação exclusiva comigo, sobretudo quando se aproximou mais de mim e me "ofereceu um chocolate".

Discutimos dois pontos do atendimento de D.: o modo como a mãe o queria dentro de casa e o encorajava muito pouco a sair de sua clausura e voltar a estudar, motivada por uma espécie de medo do mundo externo, expresso por ela, mais de uma vez, como perigoso e hostil; de outro lado, a influência, nessa mesma linha, de seu antigo médico homeopata que sugeria invariavelmente não ser ainda o momento de retomar sua vida "lá fora".

Para que se tenha uma idéia sobre o modo como a mãe de D. estava lidando com o retorno de seu filho ao mundo, gostaria de mencionar o que ela me revelou em um telefonema: contou que estava rondando pelo bairro um estuprador de meninos e meninas, que cortava seios e pênis. Quando comentei com a equipe sobre essa fala da mãe, G., diretora e terapeuta do Caps, levantou uma hipótese sobre a fantasia da mãe; se nela não estaria presente $o$ modo como ela estava lidando com a minha entrada e a do Dr. O. na vida de D.; uma expressão fantasmática de como a mãe nos sentia em relação a seu filho (como se nós lhe retirássemos tanto o lado fálico que ela assumia em casa, de mãe/mulher/terapeuta do filho, provocando dores muito cortantes nessa relação simbiótica que ela parecia manter particularmente com o filho).

Salientei que o fato de eu ter abordado esses dois temas com D. - medo de um mundo externo ameaçador, assim como a ida ao homeopata tê-lo feito recuar em suas idéias de retomar os estudos - fez com que ele faltasse a duas sessões consecutivas da análise comigo. Mas houve um saldo positivo nisso tudo: D., depois de muito resistir, voltou a sair com os amigos.

Desse modo, dava continuidade ao lado boêmio da família e ensaiava, assim, sua entrada no mundo adulto; inaugurava seu retorno ao mundo, rompendo o isolamento cultivado ao longo de mais de três anos. Não se pode esquecer de que ele, em sessão comigo, um dia deixou claro: "Eu não só abandonei a escola, mas o mundo!" Uma frase considerada pela equipe muito importante por denotar já uma grande consciência do longo processo de isolamento que ele se auto-impôs. 


\section{Falando sobre os rappers e os Racionais...}

Conversou comigo como se eu fosse alguém dos anos 60 (no fundo algo mais próximo de sua avó do que de seus pais, que se encontravam na faixa dos 40), e me falou da diferença entre os jovens dessa época e os de sua geração: "Hoje em dia o povo, enquanto dança, se bate... Fui a um show de rock no Morumbi que era assim... Por isso não gosto muito... quando saio, mudo o fuso horário (dorme durante o dia)... por isso não posso sair sempre...Pois, ou saio com os amigos, ou venho ao psiquiatra" (o horário com o Dr. O. era pela manhã, e comigo ele vinha à tarde).

Eu insisti que não precisava ser ou um ou outro, bastava coordenar os horários e dias... Mas que sentia no fundo necessidade de justificar o motivo pelo qual não lhe era possível soltar-se mais e ganhar as ruas ... - Parecia "ter medo de se perder no mundo!"

Aos poucos, foi ficando mais entusiasmado e me contou como era sair com os amigos: "Vamos em cinco no carro do irmão mais velho de um amigo. Este muito embora não tenha carta, como é a cara do irmão mais velho usa os documentos dele e saimos tarde da noite quando a polícia não está mais vigiando. Damos voltas e mais voltas até parar no Villa Lobos para comer algo... Curtimos um som...Gosto dos Rappers... é uma música de protesto... e dos Racionais, que contam como é a vida na favela".

Depois me fez um mapeamento de sua rua: "Olha, Mônica, meus amigos, todos eram pobres, mas alguns foram para a bandidagem e outros não, foram tra- balhar... eu moro no meio da rua, entre os bandidos, de um lado, e os filbinhos de papai, de outro..." (quer dizer, vivia no limite da transgressão... e como havia abandonado os estudos, sem perspectivas do que fazer, o receio do mundo exterior começava a fazer sentido, embora tivesse uma formação cultural muito boa, mas em defasagem completa com sua escolaridade).

Salientei que ele havia observado algo importante: os que eram pobres, cada um tomara o seu rumo, alguns fizeram de sua vida precária a condição para uma ascensão rápida e fácil, pela via da "bandidagem"; outros preferiram trabalhar, seguindo um caminho que exigia maior esforço, mas que era também mais seguro.

Terminamos a sessão com ele me emprestando um disco dos Racionais.

$\mathrm{Na}$ última sessão antes das férias, depois que escutei os Racionais, observei que era uma denúncia muito forte das condições de vida na favela... e o que mais me chamou a atenção foi a tensão da vida do jovem de periferia, expressa também pelo ritmo forte e até violento das músicas (dizia-me através da música de protesto como era a vida diária na periferia, quando se é considerado em princípio suspeito, pelo simples fato de ser jovem e não ser " $b a$ cana", riquinho).

Um desamparo vivido nas ruas que lembrava outro... vivido em sua família.

Em um dia próximo das férias de seus terapeutas, disse-me, em tom de desdém, que não iria ficar 
sozinho, apesar de todos tirarem férias, pois havia a Internet e que desde muito cedo aprendera a se virar sozinho... lembrou-se de quando seu pai o esqueceu na escola, na $1^{\text {a }}$ série... (desse modo, tentava tornar mais suportável a solidão, sempre justificando que já vivenciara tudo isso desde há muito tempo.. aliás, quando conversávamos, davame a impressão de estar falando com um velho... e ele mesmo reconhecia algo nessa linha).

Observei que ele devia ter sofrido muito com esse "desligamento" dos pais e também com a necessidade de muito cedo providenciar condições "psicológicas" até mesmo para ficar só e se cuidar.

Disse-me que quando era pequeno, ficava muito na rua... que só agora os pais se preocupavam com ele (ou seja, teve que renunciar ao mundo e ficar doente para ser olhado...).

Observei que agora era ele quem ficava em casa. Ponderou que seus amigos eram uma "pilha", "elétricos", enquanto ele já havia passado dessa fase... por isso, preferia ficar em casa (falou-me mais uma vez como se fosse um velho... chamei sua atenção para isso dizendo-lhe que parecia ter vivido tanta coisa num momento tão precoce de sua vida, que se cansara antes do tempo... mas que era jovem ainda e tinha muito o que viver!)

\section{Pondo em marcha um raciocínio clínico a propósito do atendimento terapêutico de $D$.}

A grande preocupação da equipe com o jovem paciente D. era seu isolamento social quase absoluto, quando o vimos pela primeira vez, com os seus 16 anos de idade, tendo abandonado a escola na $7^{a}$ série, havia mais de 2 anos.

Conforme foi se revelando sua intimidade psíquica em meio ao jogo de abertura e fechamento para o mundo e para a análise, predominava uma conduta negativista. Essa conduta, de acordo com Jeammet (2001, 2005), poderia implicar tamanha recusa em estabelecer qualquer intercâmbio com o mundo adulto e a cultura; recusa que podia chegar ao apagamento dos traços mnêmicos das relações mantidas com as figuras parentais e, até mesmo, comprometer a própria atividade do pensar. Eu diria que, no caso de D., houve realmente um estancamento do investimento do mundo - da escola, dos amigos - mas que não chegou a atingir a representação interna das figuras parentais, uma vez que as manteve sob a forma de luto e pela identificação com os gostos daqueles que lhe eram caros, mas dos quais estava afastado (sua avó, que falecera, e seu pai, que ficou gravemente doente e, depois de recuperado, casou-se de novo e foi morar no Rio de Janeiro). Aos poucos, estimulado pelo vínculo terapêutico que estabeleceu comigo e com o Dr. O., foi procurando 
tios e amigos, mais velhos e da mesma idade, com quem passou a manter um rico intercâmbio. No entanto, havia momentos em que se apegava aos grandes feitos de personagens mágicos, que "descobriam coisas fantásticas e que se tornariam ricos em segundos"; esse apego era tão grande que o colocava em uma espécie de torpor mórbido, como se estivesse à espera desse grande dia, recusando-se a se interessar na realidade pelo que quer que fosse; uma atitude que realmente nos angustiava bastante, a nós terapeutas e à equipe do Caps (que sempre lhe propunha alguma atividade cultural coordenada por um terapeuta ocupacional). A mãe, em contrapartida, procurava retê-lo sempre, ameaçando-o ou com um mundo perigoso de fora ou com a possibilidade de haver uma piora no estado de D., caso desse um passo maior do que lhe era possível suportar.

D. parecia depositário de algo não admitido por seus pais ou que fora severamente reprimido devido às experiências negativas que tiveram com o mundo das drogas e, depois, com o advento da doença do pai. A resposta da mãe deu-se pela via mística. O interessante é que os desenhos e caricaturas mostrados por D., assim como as músicas dos rappers com as quais se identificava, pareciam constituir, mais do que um protesto genuíno, um campo fértil que servia de depositário de uma agressividade ou mesmo de uma "maldade" muito poderosa. Algo muito próximo da hipótese levantada por Donald Rinsley (1980), quando menciona, a propósito das famílias scapegoating (bode expiatório), a presença de traços geradores de uma juventude delinqüencial, mas que, no caso de D., permaneceu no limite identificatório. $\mathrm{O}$ autor lembra-nos de que pais desse tipo de paciente apresentam lacunas em seus superegos, cujas necessidades inconscientes de atuação (agressivas e sexuais) são depositadas no imaginário de seus filhos. Como nesse caso a criança não pode projetar em seus pais seus desejos onipotentes, ela se sente impotente e vazia e portadora de uma maldade muito intensa. Chamou-me a atenção o fato de que se trata de jovens que não se permitem crescer como se não tivessem sido autorizados para tanto.

No caso de D., o interessante é que o pai, apesar de distante, acabou tendo um papel importante ao dar uma "prensa" na mãe, e nos filhos também, dizendo que não poderia arcar com mais nada, que estava na hora de cada um "se virar". Foi como um chamado para D. tornar-se homem finalmente, e ele o fez arranjando emprego e separando-se das mulheres (eram três em sua casa). Mas, talvez por isso mesmo, tenha preferido ficar apenas com o terapeuta masculino, Dr. O. Nesse momento, ficou claro que, com o pai por perto ou não, daria um jeito de dar cabo de suas identificações masculinas e de seu crescimento.

108 Estilos da Clínica, 2007, Vol. XII, n²2, 100-121 
A música, os blues, o rock e os rappers, auxiliados pelo acolhimento terapêutico de sua afinidade com a música de protesto, foram lhe dando suporte de diferentes maneiras - permitindo-lhe percorrer suas fantasias; do menino mau, vivendo no limite da marginalidade, até uma forma de reter, do passado familiar, o que havia de bom gosto musical. Afastando-se do lado sombrio do que restara desse passado (com doenças, risco de morte, etc.), pôde ressignificar o presente e até mesmo salvar o que havia de vida nesse passado, sobretudo quando se deixa embalar pelas músicas de protesto com Dr. O. e ter com ele conversas sobre "coisas de homem" (como sobre o trabalho, a responsabilidade, o futuro...).

\section{M., o pianista imortal...}

M., um garoto de 13 anos, foi assim apresentado por sua mãe em uma entrevista preliminar: "Eu vejo desse modo meus dois filhos gêmeos: um (o irmão gêmeo de $M$.) é meu namorado, como se fosse o meu marido... Já M. é meu espelho. Sinto tudo por ele (em seu lugar), porque ele é como eu... delicado, sensivel... Por isso não gosto que meu marido dê bronca nele, pois sei quão ressentido ele fica... E bastou ficar ansioso, ele piora da gagueira?'

Assinalei que talvez fosse importante para M., já crescido, que pudesse enfrentar o pai e pudesse sentir por si mesmo cada situação vivida.

A mãe chorou diante desse meu assinalamento, mas disse já ter pensado nessas coisas em sua análise.

O pai reconheceu que sempre teve dificuldade de se aproximar de M., uma vez que este ficava invariavelmente sob a guarda da mãe... Mas que fora estimulado por uma psicóloga de M., com quem o garoto se tratou aos 5 anos de idade, a romper essa barreira... Assinalou, no final, que talvez fosse importante para $M$. que esse olhar que a mãe tem pelo irmão de M. - vendo-o como seu namorado - fosse também dirigido a M.!

Uma conversa cujo tom fora dado inicialmente pela mãe que, sem o saber, deixou claro que M. estava predestinado a ser: seu espelho, uma mulher... delicado e sensível! Mas o pai forçou sua entrada em cena, reconhecendo que sempre lhe fora difícil interpor-se entre a mãe e M., deixando entrever, no final, sua sensibilidade (negada pela esposa), ao apontar o lugar que M. deveria ocupar no campo do desejo materno; ele salienta a importância de o menino poder colocar-se no lugar de "namorado da mãe"!

Mas por que fora a uma psicóloga aos 5 anos?

Ficaram preocupados com os trejeitos de M. e, depois, ele adquirira uma estranha mania - costumava enfiar a calcinha de uma 
boneca em sua cabeça. Todos suspeitaram de sua homossexualidade... a escola fez observações nesse sentido... - Criou-se uma situação constrangedora para todos nós! - disse a mãe.

Nessa época, ou um pouco antes, iniciou-se a gagueira de M., que piorou demais quando se preparava para um ritual de iniciação no mundo adulto masculino, um momento muito importante em sua comunidade religiosa. O pai preparou os filhos gêmeos durante dois anos para dizer uma frase de saudação (que os garotos devem pronunciar no momento da cerimônia). M. estava indo muito bem, mas, conforme se aproximava a data em que se realizaria a cerimônia, foi piorando cada vez mais. No dia, só não foi um "desastre" porque o irmão de M. falou praticamente toda a frase no lugar dele (e por ele).

\section{E conforme foram se sucedendo as sessões com M...}

Aos poucos, foi ficando claro o pavor que M. desenvolvia diante da tarefa de tornar-se homem, ou mesmo, inicialmente, de sair do lugar destinado às crianças e às mulheres $\mathrm{e}$ experimentar ficar no "lugar dos homens" em sua comunidade religiosa! E o pai de M., como representante dessa comunidade, leva essa tarefa ao extremo: "Há que treinar, não pode errar?' E com o apelo subjacente: "Tenha êxito! Caso contrário não será aceito por nossa comunidade de homens?"
Assim, foram dadas as condições para a piora da gagueira de M.!

E preciso observar que essa cerimônia, além de ser um rito de passagem para a vida adulta e para " $a$ comunidade dos homens", significa a entrada, conforme esclarece o próprio M., do percurso para o aperfeiçoamento religioso. Durante as sessões, vão se sucedendo os homens admirados por $\mathrm{M}$. que lhe servem como modelo: seu bisavô, um senhor de muita respeitabilidade em seu país de origem, a Turquia, que, conforme ouvira dizer na família, sabia bem aconselhar (mas que de lá fora expulso por motivo de perseguição religiosa, vindo a fixar residência na Bélgica); os dirigentes religiosos da escola, que o ensinavam a interpretar os textos religiosos; e, em última instância, os três grandes sábios, "os dirigentes religiosos de maior respeitabilidade no mundo inteiro", cuja profundidade aproximava-os de uma espécie de santidade...

Mas, havia também o lado da música e seu ideal de "imortalidade".

Um dia, ele me confessou ser Chopin, o grande pianista "imortal", com o qual se identificava: "Sabe, vou tocar Mozart hoje lá no conservatório... Mas en queria tocar mesmo um dia Chopin! E Liszt, então! Há momentos extremamente dificicis nele! Mas ele é muito exibido... é só para quem pode! (referindo-se ao músico e a ele mesmo, pelos desafios que propõem as composições de Lis ₹t)... Ele podia, tinha talento, sensibilidade e mãos compridas para fazer grandes acordes... E eu, ainda não sei... se tenho talento... quer dizer, quando me vi no vídeo en gostei, foi difícil reconhecer-me como sendo aquele que tocava... como se não fosse eu... capaz de tocar tão bem?' 
Ao que lhe assinalei: "Embora a música seja sua razão de viver... onde encontrou sua felicidade... pela inspiração que the propicia... ainda não se reconhece enquanto músico e se assusta quando se vê como capaz. de sê-lo?'

M. encontrou um caminho expressivo de sua vida na música. Embora às vezes se surpreenda, reconhece com orgulho ser um virtuose no piano, ou que esteja no caminho de vir a ser. Mas, por trás dessa musicalidade exibida - seja no piano, ou no canto - há outra reprimida, truncada, que perpassa sua fala espontânea e o faz gaguejar. Quando se deixa guiar pela melodia da música, não há problemas... mas, quando é ele que tem que conduzir sua fala e dar o tom, tropeça, fracassa, sobretudo em face de situações de muita ansiedade.

Depois de segredar que seu afastamento do pai esconde uma mágoa antiga... comenta, muito constrangido, que aos 5 anos de idade teria se fantasiado de mulher, para chamar a atenção dos pais, mas o que aconteceu foi que "não abafou", muito pelo contrário, sentiu-se banido, rejeitado. Doeulhe muito, sobretudo o afastamento do pai. Desde então, vestiu uma máscara, que o protege, mas que também o esconde. Rapidamente desenhou uma máscara alegre e colorida, como as máscaras de carnaval de Veneza; e, por trás dela, uma pequena bola amarela. Disse-me ser essa bola amarela que irradia, ainda hoje, luz e força para a máscara, mas que normalmente é ocultada - o que se poderia chamar de seu "eu verdadeiro". Já a máscara é sempre risonha, enorme, mas fraqueja de quando em quando (como se o traísse de algum modo).
Mas como atua essa máscara e em que situações?

Disse-me um dia: “ $A$ ! Quando eu declamo uma peça em inglês, ou quando canto, ou mesmo fazendo uma apresentação de piano! Minha fala sai perfeita, sem um arranha?'

Contudo, por trás desse eu risonho - que procura agradar a todos e, mais ainda, visa ser o único a obter o devido reconhecimento, sonhando com a imortalidade - havia o tédio, a solidão, a falta de uma amizade verdadeira... ficando triste quando menciona esse lado menos iluminado de sua vida.

Mas de quem é tão importante esse reconhecimento?

Foi e continua sendo do pai, que um dia o rechaçara por não ter se demonstrado tão másculo, por não gostar de futebol, etc. Reconhece, entretanto, que a partir do momento em que começou a destacar-se no piano, o pai passou a orgulhar-se dele. $\mathrm{O}$ avô materno, por sua vez, após uma apresentação de M., dispôs-se a comprar, junto com os pais de M., um verdadeiro piano!(pois tinha até então apenas um teclado).

\section{A rememoração onírica e a (re)construção da "guerra" que se trava nos bastidores de uma máscara de carnaval}

"Sabe, Mônica, hoje me atrasei na reza... É que en não queria acordar, pois tive um sonho interessante..."

M., que estuda tempo integral em uma escola religiosa, mantém uma relação um tanto quanto ambi- 
valente em relação à religião. Pois, se, de um lado, interessa-se muitíssimo pelos estudos religiosos, para saber de suas origens, refletir sobre a história da humanidade e desenvolver-se a ponto de tornar-se "santo" (espiritualmente elevado); de outro, dificulta-lhe seu percurso de aperfeiçoamento no campo da música, uma vez que esse caminho dependeria de muita dedicação, para a qual concorre o tempo exigido pela religião, além das proibições relativas a escutar música em determinadas ocasiões.

E qual fora o sonho?

"Estávamos diante de uma "prova". Eu, meu irmão e mais um amigo... tivemos que percorrer um labirinto estranbo, por onde passavam pequenos dinossauros... eram inofensivos... quando, de repente, deparamo-nos com um Homem (com H maiusculo) enorme. Ele estava armado com uma lança e tínhamos de enfrentá-lo. Enquanto os dois lutavam com ele, eu me escondi atrás de uma pedra. Quando olhei para o que estava ocorrendo, vi que não havia o que temer - o homem se tornara velho, de tamanho normal e também havia engordado. E depois, as flechas que ele lançava não matavam ninguém... de repente, eu lhe roubei a flecha e o matei?'

Comentei que se tratava de uma história de um jovem que temia muito um homem mais velho; dele se escondendo, até que um dia se viu também portador de uma lança, que, aliás, ele rouba do homem mais velho, já alquebrado, e o vence, dando-lhe um golpe mortal. Um homem jovem que vence o medo do homem mais velho e o ultrapassa... talvez reproduzindo no sonho o que na realidade faz e almeja fazer nas pequenas disputas com o pai (a quem sempre ridiculariza).

"Mas, Mônica, lembrei-me daquele outro sonho sobre um bebê que ia crescendo e ficava enorme! Diga-me: qual a relação entre esses dois sonhos?"

Propôs-me uma charada, cujo sentido eu havia que decifrar!

"Pois, M., talvez a relação esteja no fato de que embora você se sinta tão pequeno e impotente diante da comunidade dos homens (a comeşar do pai) que o faz sentir-se completamente desamparado, como um bebê ffica prostrado e muito doente diante de algumas situaçoes de separação da familia, sem querer ir à escola] ... a ponto de achar que não poderá enfrentálos... Mas, aos poucos está se dando conta de que você não é tão pequeno assim, nem tampouco os homens são tão poderosos a ponto de não poderem ser enfrentados!"

Disse-me que embora houvesse a proibição de tocar ou ouvir música durante a Páscoa, ele, apoiado pelo pai, fez uma consulta a um importante dirigente religioso; o que buscaram foi saber se, no caso dele, que está num estágio avançado do aprendizado do piano, em que uma pausa por mais de um mês poderia implicar em retrocesso, se não se abriria uma exceção (como é feito usualmente aos músicos profissionais).

112 Estilos da Clínica, 2007, Vol. XII, nº 22, 100-121 
Quer dizer que estava aprendendo a "somar" com o pai, aliando-se a ele, para conquistar o reconhecimento de suas habilidades e, sobretudo, de seu crescimento perante uma comunidade mais ampla (além da comunidade e escola que freqüenta).

Noutra sessão, desenhou uma bela árvore de outono, cujas folhas amareladas caiam no chão. Deu-lhe o título: "Folhas ao vento"... que associou a mudança e renovação.Estava feliz...

\section{Um encontro e uma disputa amorosa}

Noutra sessão, ele me fala que está vivendo na escola uma espécie de disputa, sem que possa encontrar um caminho para enfrentá-la com êxito... uma disputa amorosa, no fundo, embora não a reconhecesse enquanto tal! Estava muito interessado na amizade de um garoto que recém chegara de Israel, mas outro amigo aquele que também tocava piano, "mas claro que não igual a ele" ficava disputando com ele a amizade desse garoto. "O problema era que ele queria ser o amigo número 1 do garoto e não ficar em segundo lugar?"

Mais uma vez, reproduzia-se a ameaça de exclusão, ou de banimento... que sempre o aterrorizara na relação entre ele, o pai e o irmão... cujos vestígios o incomodam, quando se defronta com os alunos do pai ou quando se vê diante de uma relação triangular entre os amigos. Queria ocupar invariavelmente o lugar principal, e por que não? Ser o único... filho amado.

\section{Reflexões sobre como anda difícil para um menino ter acesso ao masculino...}

M., um dos quatro filhos de uma família bastante religiosa, muito unida e preocupada com o bem-estar e a formação dos filhos, parecia ter tudo para dar certo. No entanto, como ele mesmo se define, ele é meio urubu, deu azar! Desde o início, seu destino estivera marcado - para ser o espelho da mãe e não... do pai... Quis conquistar o pai, identificando-se com a mãe, mas fora rechaçado. Experimentara muito cedo o ostracismo do mundo paterno e, depois, passou ele mesmo a resistir a entrar no mundo dos homens - $\mathrm{a}$ ir aos encontros com a comunidade religiosa, a deixar que o pai se aproximasse dele. A mãe, finalmente, quando M. chega aos 10 anos de idade, insiste para que ele deixe seu pai entrar em sua vida. Ele cede... no fundo, a um desejo antigo.Ao mesmo tempo, a mãe que o auxiliara a encontrar seu caminho de realização na músi- 
ca, promete-lhe um gozo eterno... dizendo-lhe que mesmo que um dia ele seja um pianista famoso irá acompanhá-lo onde quer que esteja. M., então, resiste a sair desse gozo narcísico, procurando mantê-lo por meio de uma espécie de fusão com a mãe, que, por sua vez, parece realizar sua veia artística através do filho. A mãe tem o mesmo nome da bisavó, que fora uma grande pianista e por quem M. tem muita admiração. No imaginário de M., em seus sonhos, as imagens da bisavó, da mãe e dele mesmo, como um reconhecido pianista, se superpõem.

Em relação ao olhar paterno, só passa a tê-lo voltado para si quando se destaca no piano. Pois, segundo M., para o pai, ele era um fracasso: não sabia jogar bola, não tinha amigos, não era desenvolvido fisicamente. Em contrapartida, o irmão gêmeo se destacava em todas essas esferas.

$\mathrm{Na}$ relação com ambos os pais, o que se observa é, como afirma Jeammet (2001, 2005), a fragilização dos limites - entre o que é da ordem do desejo dos pais e dos filhos, entre o dentro e o fora, entre as gerações -, ao mesmo tempo em que se dá o enfraquecimento das interdições e o aumento das exigências narcísicas. A exigência de competência e de realização narcísica do desejo dos pais por parte dos filhos, como condição do amor parental, tem impedido que a nova geração renuncie ao gozo narcísico de fusão com os pais e experimente seu próprio espaço psíquico como campo de constituição do desejo. Ao mesmo tempo, fica prejudicada a triangulação edipiana e o pró-

114 Estilos da Clínica, 2007, Vol. XII, n²2, 100-121 
prio acesso ao campo identificatório que define a diferença entre os sexos.

Sua paixão pela arte de tocar piano fica no limite entre a valorização narcísica necessária para recompor o que lhe fora retirado na primeira infância e o puro gozo narcísico, misturado com o anseio de imortalidade. A árvore genealógica e sua ancoragem em uma filiação, que ele descobre vir de longa data e de terras muito distantes, tornam-se uma boa oportunidade para ter acesso à triangulação edipiana. Um percurso, como eu lhe disse, sinuoso, em meio a um labirinto cheio de provas, para ter acesso ao masculino. Os pais, por sua vez, terão que conseguir fazer o luto da separação dos filhos, nem que seja por força da religião e dos costumes das sociedades antigas, que impõem essa separação aos 13 !

Não há como negar o papel importantíssimo da música para M. como um modo, distinto da via religiosa, de ressignificar suas origens; um modo até mesmo de salvar o passado no presente, permitindo-lhe recriar seu encontro com a comunidade dos homens, ao recuperar pela via da árvore genealógica materna, a presença, em seu espírito e em sua paixão pela música, de homens e mulheres respeitáveis que souberam cultivar a arte musical. Quando menciona querer tocar Chopin e Liszt, fica com receio de estar sendo muito ousado em suas aspirações, ao querer ganhar o mundo e ser reconhecido não apenas no interior de sua comunidade religiosa. Eis o caminho encontrado por esse jovem, não sem percalços, de se construir como pessoa, superando sua fragi- lização narcísica e ir ao encontro do masculino.

\section{Em busca de uma teorização clínico-social: uma discussão a propósito da homossexualidade psíquica como estratégia de valorização narcísica}

No caso dos garotos D. e M., ambos estavam em busca do acabamento de suas identificações masculinas, num movimento duplo de estruturação narcísica em novas bases, bem como de construção de sua autonomia. O primeiro, quando sai do isolamento, só quer companhias masculinas, chegando a considerar que as namoradas dos amigos, quando aparecem, é para atrapalhar. O segundo, embora pareça caminhar pela via da resolução negativa do Complexo de Édipo, ainda não definiu sua escolha. A construção de uma escolha "homofílica" não se faz sem intensa ambivalência dos sentimentos de amor e ódio nutridos pelo pai; ambivalência que manteve abafada sob a "máscara", mas que se vê traída pela gagueira e, depois, exacerbada diante dos apelos paternos para que não falhasse no cerimonial de entrada na comunidade dos homens.

Não se pode deixar de mencionar a presença de um pai demissionário, no caso de D., que o salva no último minuto, ao exigir que comece a ganhar seu próprio sustento; ao mesmo tempo em que fica claro o amor homofílico pelos homens à sua 
volta (que mais pode ser considerado expressão de uma homossexualidade psíquica temporária como forma de completar suas identificações masculinas, assim como uma "solução" encontrada para a "saída de cena" definitiva de seu pai demissionário, que dele se afastara conforme se intensificou o vínculo terapêutico de D.).

E no caso de M? Seu problema com a figura paterna deve-se, ao contrário, ao excesso da presença paterna no imaginário de todos da família. A configuração edipiana de $\mathrm{M}$. parece estar transitando entre uma bitriangulação edipiana - tal como formulada por Green (1980) e retomada por Brusset (1990), que os autores atribuem aos funcionamentos-limite - e a resolução negativa do complexo de Édipo. Green (2000) sustenta até mesmo a hipótese de uma bi-triangulação em que os três personagens do conflito edipiano mascaram, na verdade, uma relação binária com um só objeto, dividido em suas frações boas e más.

Analisemos mais aprofundadamente essa questão.

\section{O apagar do $\mathrm{Pai}^{3}$... e a bi-triangulação na clínica dos casos-limite na adolescência}

No caso de M., é interessante observar como essa bi-triangulação aparece associada mais a uma tonalidade histérica e menos a um funcionamento-limite propriamente dito, uma vez que as condições para a sua edipificação parecem estar mais preservadas.

Não se pode esquecer que a questão do pudor e das estratégias de sua preservação encontrava-se - a despeito do "grampo materno" - mais preservada no segundo paciente (M.), do que no primeiro (D.). Há toda uma discussão complexa acerca disso e a respeito da qual seria interessante salientar ao menos que o pudor cumpre uma função protetora do narcisismo. Sua tarefa é, como salienta CinqMars (2002), modelar a pulsão escópica (responsável na criança pelo prazer de ver e de se exibir) de modo que não faça transbordar o $\mathrm{Eu}$, fazendo-o resistir a tudo o que possa haver de excessivo nas exigências do SE ou das exortações do Ideal de Eu. E nos casos em que o pai encontra-se ausente para mediar a relação entre mãe e filha, ou mesmo entre mãe e filho, como no caso de D., abre-se espaço para uma verdadeira relação invasiva da mãe sobre o imaginário do filho. E no caso de M? Quando prevalece um grau excessivo de exigências de conduta moral, em detrimento da qualidade do vínculo afetivo, como fica a reconstrução, por que passa todo adolescente, desse espaço de pudor, de tal modo que lhe permita a alternância entre o desejo pelo outro e o retorno sobre sua intimidade? É preciso ver em que medida o espaço para ser ele mesmo (sem a necessidade de que o outro fale por ele, em seu lugar) ficou prejudicado; não apenas em razão de uma relação fusional mantida com a mãe, mas devido ao peso 
das exigências morais que lhe interceptaram o acesso ao mundo masculino.

Eu acrescentaria ainda que, no caso do menino, parece bastante complicada a tarefa de evadir-se do "agarramento" materno, sobretudo quando está ausente a rivalidade para com o progenitor do mesmo sexo. Nesse caso, o rapaz desenvolve em relação à mãe, um misto de amor filial e de amor entre namorados ou até mesmo entre marido e mulher, o que se vê agravado diante do afastamento da figura paterna...e, sendo assim, talvez o que reste seja a solidão, trancafiar-se no quarto (como no caso de D.); ou, como no caso de M., que se esconde por trás de uma máscara para ser aceito, crescer e preservar sua intimidade e, mais do que isso, o seu eu. Ocorre que nem sempre isso é possível, uma vez que o retraimento pode vir acompanhado de intensas vivências desagregadoras, como ocorreu com D., e, no caso de $\mathrm{M}$, em que ficou congelada a definição de sua sexualidade.

\section{Criando pude me curar... a música e o desabrochar do masculino na adolescência}

Freud (1914/1992), em Introdução ao narcisismo, elabora uma questão fundamental para se pensar a "virada criativa" que cada um dos adolescentes acima mencionados pode dar em suas vidas a partir de seu apego à música: "De onde provém, no final das contas, no interior da vida psíquica, essa necessidade de 
sair das fronteiras do narcisismo e investir a libido em objetos exteriores?” (Freud, 1914/1992, p. 91).

$\mathrm{O}$ autor responde a essa questão à luz dos seguintes versos de Heine: "A doença é o último fundamento de todo o impulso criador. Criando, pude me curar. Criando, encontrei a saúde" (Freud, 1914/1992, p. 91).

Adverte-nos Freud de que até determinado limite, o egoísmo (supondo-se praticamente equivalentes, no caso, libido e interesse do ego) protegeria o indivíduo da enfermidade. Em seguida, contudo, imporse-ia a necessidade de amar, como forma de impedir a doença.

Considerando que na adolescência observa-se muitas vezes, conforme já salientaram Jeammet e Corcos $(2001,2005)$, uma maleabilidade psíquica muito maior do que no adulto, é mais adequado nos referirmos a organizações do que a estruturas. Foi o que pude observar nos dois casos. Muitas vezes, a solidão era acompanhada de projeções de grande sucesso no futuro, de forma absolutamente mágica: no caso de D. - que imaginava para si a possibilidade de inventar algo que desse muito dinheiro e projeção, sem muito esforço, como imaginava ter sido o caso de Bill Gates; no caso de M. - que almejava ser o pianista mais reconhecido do mundo, exigindo de si muito empenho nos estudos para que pudesse alcançar a imortalidade dos grandes músicos. Ambos, de algum modo, sentiam falta de um olhar paterno que se voltasse primordialmente para eles e não para si próprios, como acon- tecia com seus pais, bastante necessitados de amplo reconhecimento narcísico. Então, por meio de sonhos de muito sucesso, tratavam de compensar a falta... do pai.

Para os dois - D. procurando cultivá-la e M. tocá-la com um preciosismo sem igual - a música parecia cumprir uma função objetalizante, tal como salientara Green (1993) a propósito da sublimação estética ou de qualquer outra transformação psíquica que envolva a criatividade. $\mathrm{E}$ isso se deu, a meu ver, exatamente porque parecia propiciar-lhes, na falta de um prazer compartilhado com o pai de fazer-se homem (impossibilitado pelo modo desligado de um e intrusivo do outro), gozar de outro modo; gozar fazendo-se acompanhar de objetos amados (da cultura), com a vantagem de que estes só desaparecem quando os abandonamos.

Em Le moi et le ça, Freud (1923/ 1991) defende o caráter dessexualizado e sublimado da libido narcísi$\mathrm{ca}$, o que poderia ocasionar o desintrincamento das pulsões e pôr em risco a unicidade do eu. Diferentemente, dessa posição, Green, em seu livro Le travail du negatif (1993), sugere que em primeiro lugar a sublimação não cala as exigências da pulsão erótica (como ficou claro no interesse mais recente de M. em ser o melhor amigo de um garoto recémchegado à escola); o que há, segundo o autor, não é propriamente uma dessexualização, mas um engano: o eu sublimado e dessexualizado só renuncia à satisfação sexual propriamente dita, acreditando na possibilidade de se oferecer uma "satisfação superior". 
No caso do adolescente, todavia, há outra criação em jogo, a de seus próprios eu, ou, mais especificamente, como nos casos dos garotos aqui apresentados - a recriação do masculino. No caso de D., a música trazida para a análise permitiulhe tornar presentes de maneira significativa os objetos amados ausentes (sobretudo a avó, mas também o pai) e a estrutura familiar perdida, para depois concluir o luto da fragmentação familiar e do pai, que se demitira definitivamente de sua função. Apoiando-se, depois de algum tempo de análise, sobretudo na figura do Dr. O., seu amigo mais velho, profundo conhecedor de rock e blues, D. sai da posição de contemplação e "resolve" empenhar-se em construir seu masculino.

M., que claudica e gagueja na entrada da comunidade dos homens, encontra na música uma forma de se "narcisizar", assim como de se "edipificar", atraindo o interesse do pai para si e... depois, o dos garotos. A análise está lhe permitindo ir ao encontro do masculino e da definição da escolha de objeto, sem o concurso da condenação moral e de preconceitos.

E por que a música teria sido tão importante para a subjetivação dos dois garotos?

No caso deses jovens - embora um se dedique à música clássica e outro ao rock -, ambos parecem andar na contramão das tendências massificantes da sociedade (da arte leve ${ }^{4}$, uma vez que buscam inspiração no que não está na moda, no que se perdeu. E, assim, encontram a possibilidade de se individuar (e de construir o masculino a seu modo), por meio de ritmos e melodias há muito, abandonados pela maioria dos jovens (mesmo os jovens que curtem o rock hoje não o fazem como uma forma de protesto ao status quo, mas para extravasar sensações - como, por exemplo, nos bailes punks, em que se costuma dançar dando socos uns nos outros).

Como no caso dos adolescentes o que está em questão em sua busca na música é constituir uma nova "pele narcísica" (moi-peau, cf. Anzieu, 1985), reconstruir os seus eus em novas bases e, assim, dar novos contornos a seu "ser masculino", parece essencial que busquem inspiração na música; mas na música não massificada, uma vez que é mais provável que esta lhes permita- o encontro com o sexual pela não realização do toque ${ }^{5}$, algo que, diante de pais narcísicos (como parecia ser o caso dos pais desses jovens), ficava muito excitante e ameaçador. A música será, para ambos, o meio de, à meia distância, espelhar-se na tradição familiar e de dar contornos a si mesmos.

Esse processo, contudo tende a ser dificultado, quando não muitas vezes impossibilitado, uma vez que a tendência à flutuação de princípios e à dessocialização radical acompanha o hiper-individualismo de nossos tempos. Essa tendência, conforme salienta Lipovetsky (1993), tem apenas aumentado as dificuldades nas relações amorosas e a delimitação de espaços internos e externos entre as gerações. 


\begin{abstract}
MUSIC AND PSYCHOANALYSIS BETWEEN ADOLESCENTS

This is a discussion about two clinical cases related to the attendance of male adolescents. Despite of the differences in their ways of lives, costumes and traditions, they presented something in common: a twisted manner to reach masculinity. Due to the lack of a paternal look really turned to them, they found in music the narcissist anchorage that was missing. During the analysis, they had the possibility for an a posteriori elaboration of their musical via.
\end{abstract}

Index terms: access to masculinity; psychic homosexuality; aesthetical sublimation; adolescents; music

\section{RESUMEN}

LA MÚSICA Y EL PSICOANÁLISIS ENTRE LOS ADOLESCENTES

Tratase de una discusión de dos casos clínicos, relativos al atendimiento de adolescentes del sexo masculino. Los dos casos, a pesar de las diferencias de sus modos de vida, costumbres y tradiciones, presentan algo en comin: una forma sinuosa de encuentro con lo masculino y que, frente a la falta de una mirada paterna que se vuelva realmente hacia ellos, encuentran en la música el anclaje narcísico que les falta. $Y$, en el análisis, la posibilidad de elaboración a-posteriori de un trayecto de alguna manera ya recorrido por la vía musical.

Palabras clave: acceso a lo masculino; homosexualidad psíquica; sublimación estética; adolescentes; música

\section{REFERÊNCIAS BIBLIOGRÁFICAS}

Adorno, T. W. \& Horkheimer, M. (1985). Dialética do esclarecimento (G. A. de Almeida, trad.). Rio de Janeiro: Jorge Zahar. (Trabalho original publicado em 1947).

Amaral, M. do (2003). A adolescência na contemporaneidade - reflexões sobre a vida danificada. In M. L. de Oliveira (Org.). Educação e Psicanálise: história, atualidade e perspectivas (pp. 195-215). São Paulo: Casa do Psicólogo.
(2004). A sublimação estética nos interstícios da cultura contemporânea. In I. Carone (Org.). Psicanálise fim de século ensaios críticos. (pp. 89-118). São Paulo: Hacker.

André, J. et Chabert, C. (2004). L'oubli du père.Paris: PUF.

Anzieu, D. (1985). Le moi-peau. Paris: Dunod.

Brusset, B. (1990). Le père dans les états limites. Journal de la Psychanalyse de l'enfantLa fonction paternelle, 11, 88-108.

Chabert, C.(1999). Les fonctionnements limites: quelles limites?. In J. André (Org.). Les états limites (pp.93-122). Paris: PUF.

Cinq-Mars,J. M. (2002). Quand la pudeur prend corps. Paris: PUF.

Freud, S. (1977). Rémemoration, répetition, perlaboration. In S. Freud, La techinique psychanalytique (A. Berman, trad., pp.105-115). Paris: PUF. (Trabalho original publicado em 1914)

- (1991). Le moi et le ça In Oeuvres Complètes (J. Laplanche, trad.,Vol. XVI, pp. 255-30). Paris: PUF. (trabalho original publicado em1923)

(1992).Pour introduire le narcisisme. In La vie sexuelle (D. Berger, J. Laplanche et coll., trad., pp. 81-105). Paris: PUF. (Trabalho original publicado em1914)

Green, A. (1980). La folie privée. Psychanalyse des cas limites. Paris: Gallimard.

. (1993). Le travail du négatif.Paris: Ed.Minuit.

(2000). Hysterie et états limites: chiasme. Nouvelles perspectives. In A. Le Guen et al. Hysterie. Monographies de Psychanalyse (pp.139-162). Paris: PUF.

Jeammet, P. \& Corcos, M. (2001). Évolution des problématiques à l'adolescence: l'emergence de la dépendance et ses aménagements. Paris: Doin.

(2005). Novas problemáticas da adolescência: evolução e manejo da dependência (M. Amaral e col., trad.). São Paulo: Casa do Psicólogo.

120 Estilos da Clínica, 2007, Vol. XII, nº 22, 100-121 
(1989). Libertés internes et libertés externes, importance et spécificté de leur articulation à l'adolescence (1789-1989). L'enfant, l'adolescent et les libertés,65-95.

.(1994) Approche Psychodynamique de la psychopathology de l'agir à l'adolescence. Bulletin de LACIRP, Adolescence et psychanalyse - Journée des CMPP de Besançon, 2,75-92.

Lipovetsky, G. (1993). L'Ére du vide. Essays sur l'individualisme contemporain. Paris: Gallimard.

Rinsley, D. B. (1980). Diagnosis and Treatment of Borderline and Narcissistic Children and Adolescents. Bulletin of the Meninger Clinic, 44 (2), 147-170.

\section{NOTAS}

${ }^{1}$ Centro de Atenção Psicossocial da Infância e da Adolescência do Município de São Paulo, pertencente ao Distrito da Lapa.

2 Prefiro essa designação, apoiando-me nas idéias desenvolvidas por Chabert (1999).

3 Tema que foi objeto de ampla reflexão no livro de mesmo título, L'oubli du père, organizado por André, J. et Chabert, C. (2004).

4 Adorno e Horkheimer fazem, em Dialética do esclarecimento (1947), uma distinção entre a grande arte (séria) e a arte leve (de entretenimento), sustentando que enquanto o segredo da primeira consiste em apresentar a "satisfação como promessa rompida", na segunda, o segredo se desfaz e corre o risco de se ver substituído pelo "prazer preliminar não sublimado que o hábito da renúncia há muito mutilou e reduziu ao masoquismo" (1947, p.131).

${ }^{5}$ Sobretudo se ponderarmos sobre a particular dialética apontada por Green (1993) entre a sublimação e o recalque, em que "a não realização do toque" seria a condição para a dinâmica do desvio-atração da pulsão para fins não sexuais (essencial para a sublimação). Uma idéia muito próxima da que é sustentada por Adorno (1947), que condicionou a sublimação estética à "promessa rompida de satisfação", que é possibilitada pela arte séria e não pela arte leve ou massificada. (cf. salientei em artigo sobre o tema, Amaral, 2004). monicagta@usp.br

Recebido em janeiro/ 2007. Aceito em abril/2007. 